\title{
Algoritma Pemrograman dan Struktur Data
}

\author{
Erwan suganda Putra \\ 195120045 \\ Fakultas Komputer \\ Erwansuganda.student@umitra.ac.id
}

\begin{abstract}
Struktur data adalah untuk mengorganisasikan data sedemikian rupa sehingga implemental ( penerapan ) atau pemeliharaan logika program menjadi lebih terstruktur. Dalam istilah ilmu komputer, struktur data adalah cara penyimpanan, pengorganisasian, dan pengaturan data di dalam media penyimpanan komputer sehingga data tersebut dapat digunakan secara efisien.

Bahasa pemprograman turbo pascal secara umum yang dilakukan program adalah kumpulan instruksi atau perintah yang disusun sedemikian rupa sehingga mempunyai uritan logika yang tepat untuk menyelesaikan suatu persoalan.

Yaitu, salah satu aplikasi program tersebut adalah turbo pascal,materi kuliah struktur data akan disampaikan dengan mengunakan logika terbo pascal.
\end{abstract}

\section{- Algoritma dan Struktur Data}

algoritma merupakan jantung semua program yang merupakan semua urutan langkah sistematis dan dirancang untuk menyelesuaikan suatu masalah spesifik dan dengan usaha yang paling minimal.

- Karakteristik Algoritma :
$>$ Input
$>$ Output
$>$ Definite (jelas)
$>$ Efective
$>$ Terminate (berakhit) 


\section{Langkah - langkah pembuatan program}

$>$ Mendefisikan permasalahan

Ditahapan ini kita harus mengerti dengan baik mengenai permasalahan yang ingin di selesaikan

$>$ Membuat rumusan untuk pemecahan masalah

Disini kita dapat membuat rumusan algoritma untuk pemecahan masalah tersebut.dapat disusun dalam bentuk pseudocode maupun flowchart

Ex:A.pseudocode

Mulai

Input ( Bilangan 1)

Input ( Bilangan 2)

Hasil = Bilangan $1+$ Bilangan 2

Output ( Hasil )

Selesai

* Flowchart

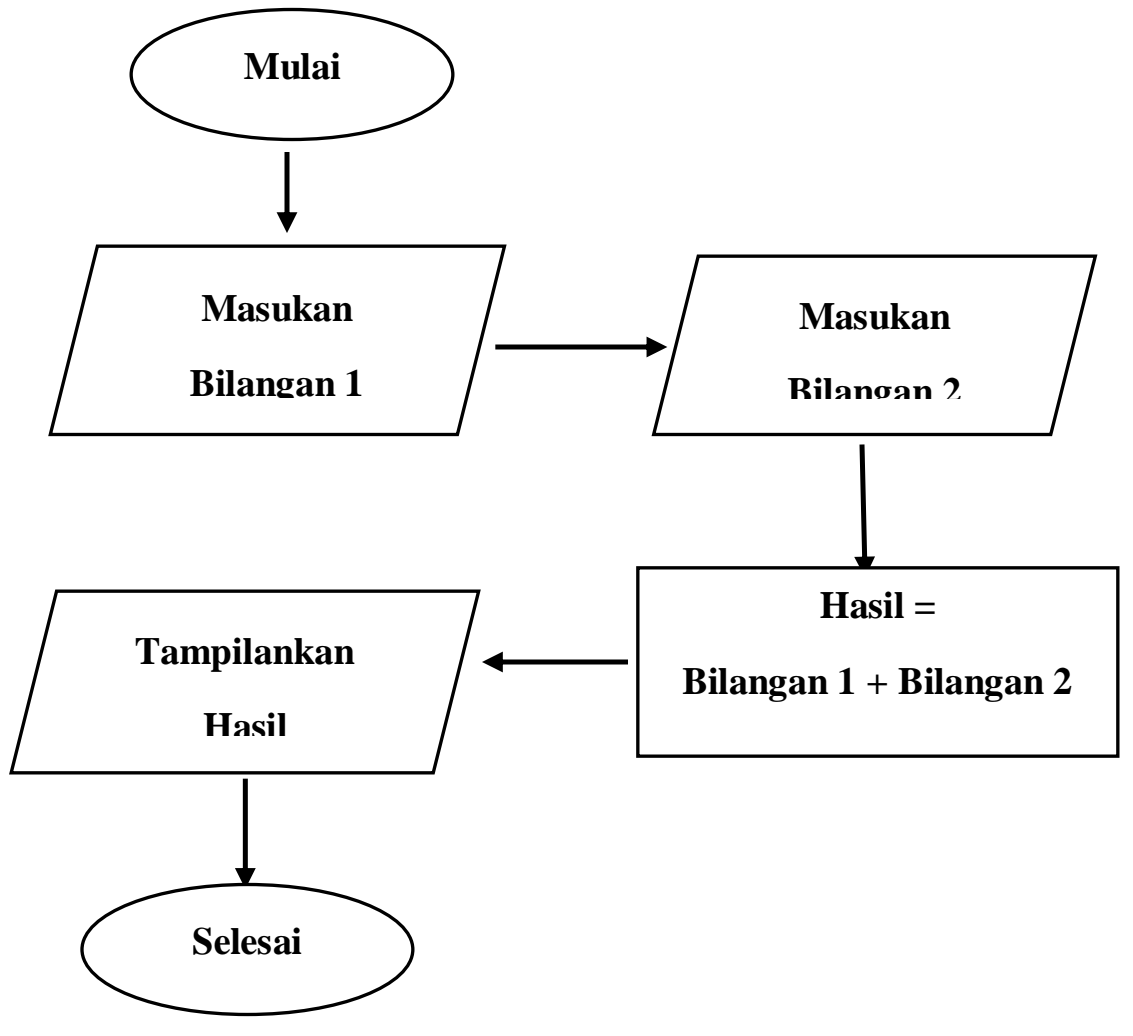


- Contoh:

Menghitung Luas Segitiga

Algoritma Menghitung Luas Segitiga

Analisis :

$>$ Input : a (alas) dan $\mathrm{t}$ (tinggi)

$>$ Luas Segitiga $=a^{*} t / 2$

Algoritma :

> Masukan nilai alas (a) dan nilai tinggi segitiga (t)

$>$ Maka untuk menghitung luas digunakan rumus alas dengan tinggi yang sudah ditentukan

> Rumus untuk menghitung Luas Segitiga yaitu $\mathrm{L}=1 / 2 * \mathrm{a} * \mathrm{t}$

> Nilai L (Luas) akan dicetak sebagai output ke perangkat output (keluaran)

Flowchart Menghitung Luas Segitiga

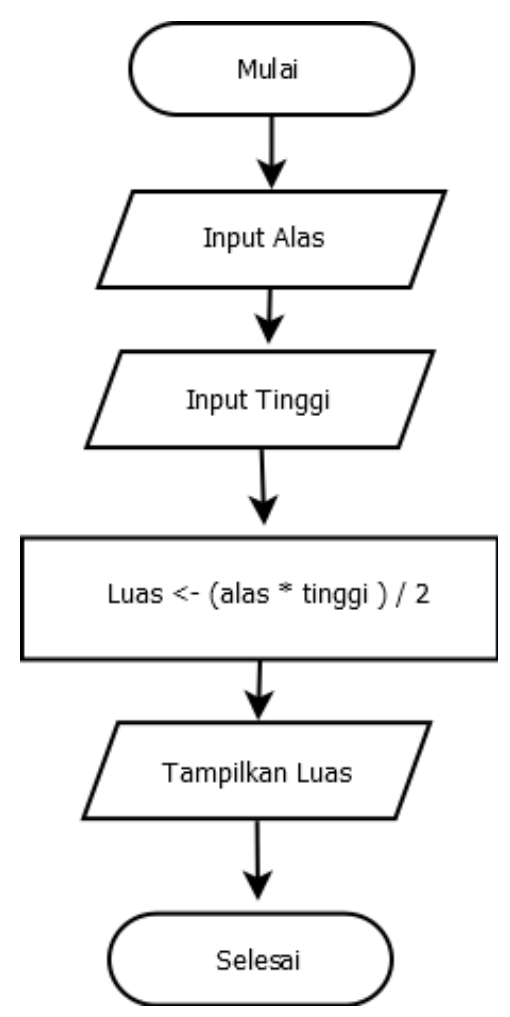




\section{A. PENDAHULUAN}

Materi kuliah section 01 membahas tentang algoritma pemprograman dan struktur data dalam suatu algoritma merupakan jantung semua program yang merupakan semua urutan langkah sistematis dan dirancang untuk menyelesuaikan suatu masalah spesifik dan dengan usaha yang paling minimal.

\section{B. PEMBAHASAN / STUDI KASUS}

\section{$\checkmark$ Pengertian Struktur Data}

Struktur data adalah untuk mengorganisasikan data sedemikian rupa sehingga implemental ( penerapan ) atau pemeliharaan logika program menjadi lebih terstruktur. Dalam istilah ilmu komputer, struktur data adalah cara penyimpanan, pengorganisasian , dan pengaturan data di dalam media penyimpanan komputer sehingga data tersebut dapat digunakan secara efisien.

\section{$\checkmark$ Bahasa pemprograman turbo pascal}

secara umum yang dilakukan program adalah kumpulan instruksi atau perintah yang disusun sedemikian rupa sehingga mempunyai uritan logika yang tepat untuk menyelesaikan suatu persoalan

\section{$\checkmark$ Langkah - langkah pembuatan program}

a. Mendefisikan permasalahan

Ditahapan ini kita harus mengerti dengan baik mengenai permasalahan yang ingin di selesaikan

b. Membuat rumusan untuk pemecahan masalah

Disini kita dapat membuat rumusan algoritma untuk pemecahan masalah tersebut.dapat disusun dalam bentuk pseudocode maupun flowchart

Ex:A.pseudocode

Mulai

Input ( Bilangan 1)

Input ( Bilangan 2)

Hasil $=$ Bilangan $1+$ Bilangan 2

Output ( Hasil )

Selesai 


\section{ID SECURITY \\ QWTD4452377-ASP-5244166}

\section{KESIMPULAN}

Kesimpulan dari materi ini adalah Dalam istilah ilmu komputer, struktur data adalah cara penyimpanan, pengorganisasian, dan pengaturan data di dalam media penyimpanan komputer sehingga data tersebut dapat digunakan secara efisien.

\section{E. DISKUSI}

Saya bersama teman saya bernama redo mendiskusikan tentang pengertian Algoritma Pemrograman dan Struktur Data ini dengan sangat baik hasil diskusi dari materi ini adalah untuk mengorganisasikan data sedemikian rupa sehingga implemental ( penerapan ) atau pemeliharaan logika program menjadi lebih terstruktur. Dalam istilah ilmu komputer, struktur data adalah cara penyimpanan ,pengorganisasian, dan pengaturan data di dalam media penyimpanan komputer sehingga data tersebut dapat digunakan secara efisien 


\section{F. REFERENCE}

[1] O. M. Febriani and A. S. Putra, "Sistem Informasi Monitoring Inventori Barang Pada Balai Riset Standardisasi Industri Bandar Lampung," J. Inform., vol. 13, no. 1, pp. 90-98, 2014.

[2] A. S. Putra, "Paperplain: Execution Fundamental Create Application With Borland Delphi 7.0 University Of Mitra Indonesia," 2018.

[3] A. S. Putra, "2018 Artikel Struktur Data, Audit Dan Jaringan Komputer," 2018.

[4] A. S. Putra, "ALIAS MANAGER USED IN DATABASE DESKTOP STUDI CASE DB DEMOS."

[5] A. S. Putra, "COMPREHENSIVE SET OF PROFESSIONAL FOR DISTRIBUTE COMPUTING."

[6] A. S. Putra, "DATA ORIENTED RECOGNITION IN BORLAND DELPHI 7.0."

[7] A. S. Putra, "EMBARCADERO DELPHI XE 2 IN GPU-POWERED FIREMONKEY APPLICATION."

[8] A. S. Putra, "HAK ATAS KEKAYAAN INTELEKTUAL DALAM DUNIA TEKNOLOGY BERBASIS REVOLUSI INDUSTRI 4.0."

[9] A. S. Putra, "IMPLEMENTASI PERATURAN PERUNDANGAN UU. NO 31 TAHUN 2000 TENTANG DESAIN INDUSTRI BERBASIS INFORMATION TECHNOLOGY."

[10] A. S. Putra, "IMPLEMENTATION OF PARADOX DBASE."

[11] A. S. Putra, "IMPLEMENTATION OF TRADE SECRET CASE STUDY
SAMSUNG MOBILE PHONE."

[12] A. S. Putra, "IMPLEMENTATION PATENT FOR APPLICATION WEB BASED CASE STUDI WWW. PUBLIKLAMPUNG. COM."

[13] A. S. Putra, "IMPLEMENTATION SYSTEM FIRST TO INVENT IN DIGITALLY INDUSTRY."

[14] A. S. Putra, "MANUAL REPORT \& INTEGRATED DEVELOPMENT ENVIRONMENT BORLAND DELPHI 7.0."

[15] A. S. Putra, "PATENT AS RELEVAN SUPPORT RESEARCH."

[16] A. S. Putra, "PATENT FOR RESEARCH STUDY CASE OF APPLE. Inc."

[17] A. S. Putra, "PATENT PROTECTION FOR APPLICATION INVENT."

[18] A. S. Putra, "QUICK REPORT IN PROPERTY PROGRAMMING."

[19] A. S. Putra, "REVIEW CIRCUIT LAYOUT COMPONENT REQUIREMENT ON ASUS NOTEBOOK."

[20] A. S. Putra, "REVIEW TRADEMARK PATENT FOR INDUSTRIAL TECHNOLOGY BASED 4.0."

[21] A. S. Putra, "TOOLBAR COMPONENT PALLETTE IN OBJECT ORIENTED PROGRAMMING."

[22] A. S. Putra, "WORKING DIRECTORY SET FOR PARADOX 7."

[23] A. S. Putra, "ZQUERY CONNECTION IMPLEMENTED PROGRAMMING STUDI CASE PT. BANK BCA Tbk."

[24] A. S. Putra, D. R. Aryanti, and I. 
Hartati, "Metode SAW (Simple Additive Weighting)

sebagai Sistem Pendukung Keputusan Guru Berprestasi (Studi Kasus: SMK Global Surya)," in Prosiding Seminar Nasional Darmajaya, 2018, vol. 1, no. 1, pp. 85-97.

[25] A. S. Putra and O. M. Febriani, "Knowledge Management Online Application in PDAM Lampung Province," in Prosiding International conference on Information Technology and Business (ICITB), 2018, pp. 181-187.

[26] A. S. Putra, O. M. Febriani, and B. Bachry, "Implementasi Genetic Fuzzy System Untuk Mengidentifikasi Hasil Curian Kendaraan Bermotor Di Polda Lampung," SIMADA (Jurnal Sist. Inf. dan Manaj. Basis Data), vol. 1, no. 1, pp. 21-30, 2018.

[27] A. S. Putra, H. Sukri, and K. Zuhri, "Sistem Monitoring Realtime Jaringan Irigasi Desa (JIDES) Dengan Konsep Jaringan Sensor Nirkabel," IJEIS (Indonesian J. Electron. Instrum. Syst., vol. 8, no. 2, pp. 221-232.

[28] D. P. Sari, O. M. Febriani, and A. S. Putra, "Perancangan Sistem Informasi SDM Berprestasi pada SD Global Surya," in Prosiding Seminar Nasional Darmajaya, 2018, vol. 1, no. 1, pp. 289-294. 